This article was published in Meat Science, 96 (1), 82-87, 2014

http://dx.doi.org/10.1016/j.meatsci.2013.05.042

\title{
Evolution of amino acids and biogenic amines throughout storage in sausages made of horse, beef and turkey meats
}

Mohamed A. Rabie ${ }^{a, b}$, Cidalia Peres ${ }^{b}$, F. Xavier Malcata ${ }^{b, c},_{*}$

a Department of Food Science, Faculty of Agriculture, Zagazig University, Egypt

b Instituto de Tecnologia Química e Biológica, Universidade Nova de Lisboa, Apartado 127, P- 2781-901 Oeiras, Portugal

c Department of Chemical Engineering, University of Porto, Rua Dr. Roberto Frias, P-4200-465 Porto, Portugal

\begin{abstract}
The changes in concentration of free amino acids and biogenic amines, along 28 d of storage at $4{ }^{\circ} \mathrm{C}$, were monitored in a wide range of European ripened sausages manufactured from horse, beef and turkey meats. Generally speaking, both chemical families became more concentrated with elapsing time - but rather distinct patterns were followed in each meat type: total free amino acids increased by 13 -fold in the case of horse sausages, and 5 -fold in the case of beef sausages, but decreased to one third in the case of turkey sausages; and total biogenic amines attained $730 \mathrm{mg} / \mathrm{kg}$ in turkey sausages, $500 \mathrm{mg} / \mathrm{kg}$ in beef sausages and $130 \mathrm{mg} / \mathrm{kg}$ in horse sausages by $28 \mathrm{~d}$ of refrigerated storage. For putrescine, maximum levels of $285 \mathrm{mg} / \mathrm{kg}$ were attained in turkey and $278 \mathrm{mg} / \mathrm{kg}$ in beef sausages; for cadaverine, maximum levels of $6 \mathrm{mg} / \mathrm{kg}$ in turkey and $9 \mathrm{mg} / \mathrm{kg}$ in beef; and for histamine, maximum levels of $263 \mathrm{mg} / \mathrm{kg}$ in turkey and $26 \mathrm{mg} / \mathrm{kg}$ in beef. Hence, public safety concerns may be raised in the case of turkey sausages.
\end{abstract}

\section{Introduction}

Dry fermented sausages are popular delicacies in various parts of the world; their quality in terms of slicing ability, firmness, color and taste hinges critically on the levels of proteolysis attained during ripening. However, adventitious (or otherwise added) microflora will uptake free amino acids as nutrients and may bring about decarboxylation thereof for energetic purposes, given the nutritionally poor environment and the relatively long storage period (Konings et al., 1997), to yield biogenic amines. Common examples of the latter are histamine produced from histidine, putrescine from 
ornithine, cadaverine from lysine, and tyramine from tyrosine; spermidine and spermine are sequentially produced from putrescine (Eitenmiller \& de Souza, 1984). Microorganisms possessing decarboxylating capacity encompass pathogens belonging to the Bacillus, Pseudomonas, Escherichia and Salmonella genera, as well as such food borne starters as Lactobacillus, Enterococcus, Lactococcus and Leuconostoc spp. (Edwards, Sandine, \& Public, 1981). Bio- genic amines may raise safety issues due to their toxicity (Luthy \& Schlatter, 1983), associated with e.g. hypertension, headaches, fever, nausea, urticaria, and gastric and intestinal ulcers; they can even be precursors of carcinogenic nitrosamines (Patterson \& Mottram, 1974). The Food and Drug Administration has established a maximum tolerance level of $100 \mathrm{mg} / \mathrm{kg}$ for histamine in flesh (FDA, 1990); EFSA has recently established a daily maximum intake of $50 \mathrm{mg}$ of histamine, and 600 $\mathrm{mg}$ of tyramine can be considered safe for healthy individuals, although such limits may be drastically reduced in case of reported intolerance or use of monoamine oxidase inhibitor drugs (EFSA, 2011).

High levels of putrescine and cadaverine appear to potentiate the toxicity of histamine, as well as tyramine (Taylor, 1985). Although re- liable dose-response data are not available pertaining to human consumption, the limited number of animal studies published so far have suggested an oral toxicity of $180 \mathrm{mg} / \mathrm{kg}$ body weight/day in Wistar rats (EFSA, 2011).

Spermidine and spermine are found in almost all sausages manufactured from fresh beef and pork; spermidine averages at $3.0 \mathrm{mg} / \mathrm{kg}$, whereas spermine ranks in $33.5-39.8 \mathrm{mg} / \mathrm{kg}$ (Hernandez-Jover, Izquierdo-Pulido, Veciana-Nogués, \& VidalCarou, 1997). Further- more, several authors working with such Spanish dry sausages as chorizo, fuet, sobrasada and salsichón (Bover-Cid, Izquierdo-Pulido, \& Vidal-Carou, 2000; Bover-Cid, Miguélez-Arrizado, \& Vidal-Carou, 2001; Lorenzo, Michinel, López, \& Carballo, 2000; Roig-Sagués, Hernández-Herrero, López-Sabater, Rodriguez-Jerez, \& Mora-Ventura, 1999; Ruiz-Capillas \& Jiménez-Colmenero, 2004; Santos, Jalon, \& Marine, 1985), as well as French (Buscailhon, Monin, Cornet, \& Bousset, 1994) and Iberian (Alfaia et al., 2004; Hernandez-Jover, Izquierdo-Pulido, Veciana-Nogués, \& Vidal-Carou, 1996; Martin, Antequera, Ventanas, Menitez-Donoso, \& Cordoba, 2001) dry cured hams found that tyramine and cadaverine could reach $600 \mathrm{mg} / \mathrm{kg}$, whereas putrescine was present up to $450 \mathrm{mg} / \mathrm{kg}$, and 2-phenylethylamine and tryptamine up to $50 \mathrm{mg} / \mathrm{kg}$; specifically, histamine reached $330 \mathrm{mg} / \mathrm{kg}$ in chorizo and fuet, which are thresholds that pose a health concern. On the other hand, tyramine and putrescine were the most abundant biogenic amines in dry Finnish sausages (Eerola, RoigSagués, \& Hirvi, 1998), and high levels of cadaverine were detected in Danish pepperoni (Hernandez-Jover et al., 1997). Histamine was also detected in Russian sausages, but usually not above $100 \mathrm{mg} / \mathrm{kg}$ (Hernandez-Jover et al., 1997). In the case of Turkish sausages, contents of $1,100 \mathrm{mg} / \mathrm{kg}$ of tyramine and $350 \mathrm{mg} / \mathrm{kg}$ of histamine were found in sucuks (Şenöz, Işıklı, \& Çoksöyler, 2000), and $400 \mathrm{mg} / \mathrm{kg}$ of putrescine and $250 \mathrm{mg} / \mathrm{kg}$ of tyramine in soudjoucks (Ayhan, Kolsarici, \& Özkan, 1999). 
Contaminated raw materials and poor hygienic conditions prevailing during manufacture are likely contributors to the dangerous levels of histamine found (Komprda, Neznalovà, Standara, \& Bover-Cid, 2001), and temperature abuses during storage contribute to accumulate tyramine, cadaverine and putrescine (Bover-Cid et al., 2000), namely because of contamination by Enterobacteriaceae (Halász, Baráth, Simon-Sarkadi, \& Holzapfel, 1994). Despite the above data, fermented sausages in general have been claimed as intrinsically safe for consumption owing to their reduced aw and $\mathrm{pH}$ (Ferreira \& Pinho, 2006). Hence, the effect of refrigerated storage upon the biogenic amine content of European sausages manufactured from meats other than pork or beef was not studied to date to sufficient depth, nor has its relationship with amino acid levels been established. Therefore, the aim of this work was to provide a consistent overview of the presence of biogenic amines in dry sausages, especially those manufactured from horse and turkey; and also search for public health risks derived from ingestion of those less usual sausages and associated with presence of biogenic amines.

\section{Materials and methods}

\subsection{Collection of samples}

A wide variety and a large number (210) of European ripened, dried sausages manufactured from plain horse, beef and (smoked) turkey meats, together with a small portion of pork but without nitrate/nitrite or any starter culture, were purchased from supermarkets at random right upon production, and kept refrigerated at $4{ }^{\circ} \mathrm{C}$. Seventy sausages from each type with $200 \mathrm{~g}$ in weight, 26-36 $\mathrm{mm}$ in diameter and $13-25 \mathrm{~cm}$ in length were sampled (in duplicate) by $0,7,4,21$ and $28 \mathrm{~d}$ of storage (i.e. covering their expected shelf life). Samples (3 g each) were immediately homogenized and frozen upon collection, and kept as such in packages where oxygen had been excluded by back flushing with nitrogen, until analysis was in order (usually within $48 \mathrm{~h}$ ).

\subsection{Determination of dry weight}

The reference drying method (MSZ EN ISO 1666:2000) was applied, using a WS 50 oven (MLW, Germany) for heating to $100-105^{\circ} \mathrm{C}$ until constant weight.

\subsection{Extraction of amino acids and biogenic amines}

Amino acids and biogenic amines in the samples were extracted as originally described by Simon-Sarkadi and Holzapfel (1994), and later improved by Rabie, Siliha, el-Saidy, el-Badawy, and Malcata (2010) for meat matrices: $10 \mathrm{ml}$ of $10 \%(\mathrm{v} / \mathrm{v})$ 
trichloroacetic acid was added to $3 \mathrm{~g}$ of sample, the mixture was shaken for $1 \mathrm{~h}$ using a Laboshake Ls 500i (Gerhardt, Germany), and the extract was finally filtered through Whatman No.1 filter paper. To remove fat, the extracts were kept at $-20{ }^{\circ} \mathrm{C}$ for $1 \mathrm{~d}$, and then subjected to centrifugation at $7000 \mathrm{~g}$ for $15 \mathrm{~min}$ using a $\mathrm{T} 24$ apparatus (MLW). The supernatant was finally collected and filtered through 0.25 $\mu \mathrm{m}$ membrane filters (Nalgene, USA).

\subsection{Quantitation of amino acids and biogenic amines}

Analyses of free amino acids and biogenic amines were performed using an AAA 400 amino acid analyser (Ingos, Czech Republic) equipped with a Watrex Polymer 8 ion exchange column (20 cm long, $3.7 \mathrm{~mm}$ i.d.) for amino acids, and an Ostion LG ANB ion exchange column (6 cm long, $3.7 \mathrm{~mm}$ i.d.) for biogenic amines. Free amino acids and biogenic amines in $100 \mu \mathrm{L}$-aliquots were injected into said column, and separated by stepwise gradient elution at $0.30 \mathrm{~mL} / \mathrm{min}\left(60^{\circ} \mathrm{C}\right)$, using a $\mathrm{Li}^{+}$buffer for amino acids and a $\mathrm{Na}^{+} / \mathrm{K}^{+}$buffer for biogenic amines-prepared as described in detail by Csomos and Simon-Sarkadi (2002); the total running times were 92 and $101 \mathrm{~min}$, respectively. Colorimetric detection was accomplished at 570 and $440 \mathrm{~nm}$, for amino acids and biogenic amines, after post column derivatization $\left(121^{\circ} \mathrm{C}\right)$ with ninhydrin, supplied at $0.20 \mathrm{~mL} / \mathrm{min}$ (Csomos \& Simon-Sarkadi, 2002). All analytical determinations were done in triplicate (free amino acids) and duplicate (biogenic amines).

Identification was by matching of retention times of aliquots of actual samples and chromatographic standards, whereas quantification was by peak area based on calibration curves previously prepared using chromatographic standards.

\subsection{Statistical analyses}

All experimental values pertaining to biogenic amine and amino acid concentrations were reported as average \pm standard deviation of three replicates. Statistical significance of the differences found between data was ascertained via Student's $t$-tests; a probability value, $P$, of less than $5 \%$ was considered as statistically significant. The statistical software utilized was SPSS (from SPSS Inc., Chicago IL, USA).

\section{Results and discussion}

\subsection{Free amino acids}

The evolution in concentration of 22 amino acids is depicted in Tables 1-3 for the 
three meat types. Within a $28 \mathrm{~d}$ period, their total concentration increased significantly $(P<5 \%)$ by 12.8 -fold in horse sausage and 4.8 -fold in beef sausage. Lysine, tyrosine and histidine are the chief precursors of biogenic amines in foods: all of them underwent considerable increases throughout storage as a result of microbial-mediated proteolysis, in the case of horse sausages; and lysine, in the case of beef sausages. It is well-known that the chief contributor to biogenic amine appearance is microbial pathways; this assumption also appears to hold in our case, in view of $\mathrm{pH}$ lowering as indirect evidence of microbial action (even though monitoring of viable numbers of the major microbial families was not pursued). On the other hand, the absence of nitrates/nitrites and the essentially constant levels of salt and water activity throughout storage rule out discrepancies in the resident microflora arising from such exogenous factors (Joosten, 1988).

A gradual release of amino acids throughout storage is typical in dry fermented sausages (Beriain, Lizaso, \& Chasco, 2000a; Dainty \& Blom, 1995; Hierro, Hoz, \& Ordoñez, 1999); these compounds are important for correct taste development of the final product (Montel, Masson, \& Talon, 1998). Such increasing trends were typically observed in our horse and beef sausages, and are consistent with reports by Hierro et al. (1999), Bolumar, Nieto, and Flores (2001) and Hughes et al. (2002); our data actually lie within ranges similar to those found by Beriain et al. (2000a,b); Beriain, Lizaso, and Chasco (2000b) and Bruna, Fernández, Hierro, Ordóñez, and Hoz (2000a,b).

Conversely, the total concentration of amino acids decreased 2.6 -fold $(P<5 \%)$ in turkey sausage within the $28 \mathrm{~d}$ period, thus suggesting microbial uptake (BoverCid et al., 2000; Ordóñez, Hierro, Bruna, \& Hoz, 1999) and eventual extensive conversion to biogenic amines by the surviving microflora: remember that this was the only meat type subjected to smoking, which may account for the disparate behaviour observed. As will be discussed below in further detail, the largest increase in total biogenic amines occurred also in this type of sausage. According to Ruiz et al. (1999) and Ventanas et al. (1992), free amino acids may decrease or increase in concentration depending on the prevailing chemical and enzymatic reactions, in particular amino acid decarboxylase activity of the surviving microorganisms (Virgili, Saccani, Gabba, Tanzi, \& Bordini, 2007), which is in turn dependent on the processing technique (Martin et al., 1998). A decrease in free amino acids was likewise reported during extended ripening of dry-cured ham (Alfaia et al., 2004; Buscailhon et al., 1994).

Inspection of Table 1, one realises that the main amino acids in horse sausage were methionine $\quad(0.15-23.20 \mathrm{mg} / \mathrm{kg}), \quad$ glycine $(1.54-20.96 \mathrm{mg} / \mathrm{kg})$, proline $(0.70-10.15$ $\mathrm{mg} / \mathrm{kg})$, arginine $(0.58-9.07 \mathrm{mg} / \mathrm{kg})$, glutamic acid $(0.47-8.18 \mathrm{mg} / \mathrm{kg})$, lysine $(1.15-7.24$ $\mathrm{mg} / \mathrm{kg}$ ) and tyrosine $(0.14-7.09 \mathrm{mg} / \mathrm{kg})$; altogether, they accounted for $55 \%$ of the total amino acids by $28 \mathrm{~d}$. It is interesting that the concentrations of some free amino acids were consistently lower by $21 \mathrm{~d}$ - yet no apparent rationale could be found for this 
realisation.

The predominant amino acids in beef sausage (Table 2) were alanine (7.63-63.41 $\mathrm{mg} / \mathrm{kg})$, aspartic acid (0.61-44.39 $\mathrm{mg} / \mathrm{kg})$, glycine $(2.98-20.16 \mathrm{mg} / \mathrm{kg})$, asparagine $(0.08-7.67 \mathrm{mg} / \mathrm{kg})$, leucine $(3.75-7.19 \mathrm{mg} / \mathrm{kg})$, lysine $(2.70-4.22 \mathrm{mg} / \mathrm{kg})$ and glutamine $\left(3.76^{-} 4.11 \mathrm{mg} / \mathrm{kg}\right)$; as a whole, these seven amino acids represented $93 \%$ of the total amino acids by the end of storage.

Finally, the chief amino acids in turkey sausage were alanine $(35.60-4.35 \mathrm{mg} / \mathrm{kg})$, glycine $(2.23-2.33 \mathrm{mg} / \mathrm{kg})$, lysine $(1.65-1.75 \mathrm{mg} / \mathrm{kg})$, serine $(1.22-1.55 \mathrm{mg} / \mathrm{kg})$, proline $(1.20-1.31 \mathrm{mg} / \mathrm{kg})$, leucine $(1.04-1.22 \mathrm{mg} / \mathrm{kg})$ and valine $(0.75-0.94$ $\mathrm{mg} / \mathrm{kg}$ ), as depicted in Table 3 ; they summed up $75 \%$ of the total amino acids by $28 \mathrm{~d}$.

\subsection{Biogenic amines}

The evolution of the independent concentrations of 6 biogenic amines is depicted in Fig. 1, for the three meat types; the total concentrations are, for convenience, tabulated in Tables 1-3.

The highest concentration of total biogenic amines (i.e. $730.3 \mathrm{mg} / \mathrm{kg}$ ) was found in turkey sausage, followed by beef (i.e. $496.0 \mathrm{mg} / \mathrm{kg}$ ), whereas a total of only $126.9 \mathrm{mg} / \mathrm{kg}$ was observed in horse sausage by $28 \mathrm{~d}(P<5 \%)$; note that a maximum threshold of $1000 \mathrm{mg} / \mathrm{kg}$ of total bio- genic amines has been considered as heuristic rule, in terms of danger for human health (Silla-Santos, 1996). This dominance of turkey meat correlated well with the lower levels of free amino acids observed; this was expected in view of the microbial-mediated decarboxylation pathways. Note that lactic acid bacteria (among other food-borne adventitious microorganisms) possess decarboxylase activity - chiefly tyrosine-, histidine-, lysine- and argininedecarboxylases, so availability of Tyr, His, Lys and Arg is a must, but their decreasing levels are associated with increasing levels of the corresponding biogenic amines. Rabie et al. (2010) reported total biogenic amine contents in Egyptian fermented sausage ranging from 277 to $5815 \mathrm{mg} / \mathrm{kg}$, within $30 \mathrm{~d}$ of storage, which is well above our large sample of European sausages manufactured from less conventional meats. The aforementioned distinct contents may correlate with different conditions of manufacture, besides the type of source meat and the associated variability of adventitious (or added) microflora; lack of quality control during manufacture has been claimed by Bodmer, Irmak, and Kneubühl (1999) to also play a role.

With regard to histamine specifically, the lowest level $(2.96 \mathrm{mg} / \mathrm{kg})$ was observed in beef sausage by $0 \mathrm{~d}$, and the highest $(263.45 \mathrm{mg} / \mathrm{kg})$ in turkey sausage by $28 \mathrm{~d}(P<5 \%)$; however, the content of this biogenic amine in beef sausage by $28 \mathrm{~d}(31.24 \mathrm{mg} / \mathrm{kg})$ was 3 -fold its horse counterpart ( $P$ b 5\%). This biogenic amine is directly influenced by the level of histidine, which must be in excess of normal microbial growth requirements 
(Eitenmiller \& de Souza, 1984); in all cases (except horse sausage by 28 d), the level of histidine remained essentially constant, so it appears that the excess release of that amino acid was used up in full to synthesize histamine. Taylor, Lieber, and Leatherwood (1978) reported similar results for histamine levels in various dry sausages; in Turkish sausages, histamine concentrations were $6.72-362.22 \mathrm{mg} / \mathrm{kg}$ (Şenöz et al., 2000) or $0.85-378.29 \mathrm{mg} / \mathrm{kg}$ (Bozkurt \& Erkmen, 2002), but values as low as 50 (Stratton, Hutkins, \& Taylor, 1991) and 100 (Eerola, Xavier, Lilleberg, \& Aalto, 1997), and as high as 768 (Rabie et al., 2010) and $1000 \mathrm{mg} / \mathrm{kg}$ (Erginkaya \& Varlik, 1989) have also been reported. The aforementioned levels will likely pose a risk for public health in the case of turkey sausages: recall that allowable limits for histamine are 40$100 \mathrm{mg} / \mathrm{kg}$, and levels above $100 \mathrm{mg} / \mathrm{kg}$ may already cause some degree of poisoning (Maijala, Eerola, Aho, \& Hirn, 1993). However, the actual toxicological level is difficult to establish a priori because it depends on the physiological responses of each individual, coupled with presence (or not) of other biogenic amines (Halász et al., 1994; ten Brink, Damink, Joosten, \& Huis in't Veld, 1990).

Putrescine was the chief biogenic amine found in turkey and beef sausages, and its content increased $3.4^{-}$and $7.1^{-}$fold, respectively $\quad(P<5 \%)$, as storage time elapsed. The level of this biogenic amine is supposed to correlate with its precursor free amino acid, ornithine, via a synergistic deiminase-decarboxylase mechanism (Virgili et al., 2007); however, ornithine was not detected in our sausages.

The content of tyramine remained also high in beef and turkey sausages, and a high relative increase (2.9-fold) within $28 \mathrm{~d}$ occurred in horse sausages ( $P$ b $5 \%$ ). This biogenic amine increases in content as its precursor tyrosine is released throughout ageing; this can be realised by the almost constant levels of tyrosine in beef and turkey sausages, despite the fact that this amino acid is being continuously released by proteolysis. Recall that total intakes of $10-80 \mathrm{mg} / \mathrm{d}$ of tyramine has proven toxic to sensitive people, and levels above $100 \mathrm{mg} / \mathrm{kg}$ may cause migraine (Maijala et al., 1993). These ranges are consistent with those encountered before in several Southern European sausages, e.g. Spanish chori- zo, salsichón and fuet (Bover-Cid \& Holzapfel, 1999; Hernandez-Jover et al., 1996), Austrian salami (Pechanek, Woidich, \& Pfannhauser, 1983), Italian salsiccia and soppressata (Parente et al., 2001), and Belgian fermented sausages (Ansorena et al., 2002). Shalaby (1996) suggested that tyramine levels within 100-800 mg/kg (as well as histamine levels within $50-100 \mathrm{mg} / \mathrm{kg}$, for that matter) are still compatible with Good Manufacturing Practices.

The highest content of cadaverine $(9.18 \mathrm{mg} / \mathrm{kg})$ was found in tur- key sausage by 7 $\mathrm{d}$, whereas the lowest $(1.36 \mathrm{mg} / \mathrm{kg})$ was detected in horse sausage by $0 \mathrm{~d}(P<5 \%)$; its content in beef sausage was essentially constant as storage time elapsed, but an increasing tendency in horse and a decreasing one in turkey were observed. Cadaverine originates via decarboxylation of lysine, yet the concentration of the latter increased in all types of sausage tested as time elapsed. A relatively high content of 
cadaverine (as well as putrescine) enhanced the toxicity of histamine in turkey meats (Jung \& Bjeldanes, 1979), likely due to inhibition of detoxifying enzymes.

Finally, the maximum contents of spermidine and spermine in horse sausage were 6.86 for spermidine and $18.92 \mathrm{mg} / \mathrm{kg}$ for spermine, by 0 and $28 \mathrm{~d} ; 9.85$ for spermidine and $24.54 \mathrm{mg} / \mathrm{kg}$ for spermine in beef sausage, by $28 \mathrm{~d}$; and 10.72 for spermidine and $11.30 \mathrm{mg} / \mathrm{kg}$ for spermine in turkey sausage, by 0 and $21 \mathrm{~d}$ ( $P$ b 5\%). There is in general a decreasing pattern of the concentration of spermidine (especially in the case of turkey sausage) and an increasing pattern of the concentration of spermine in all types of sausage. This realisation is consistent with the synthesis of spermine from spermidine, and of spermidine from putres- cine (Bodmer et al., 1999), although the rate of formation of putrescine is far higher, chiefly in the case of beef and turkey sausages.

\section{Conclusions}

The concentration of total free amino acids increased significantly $(P<5 \%)$ during refrigerated storage up to $28 \mathrm{~d}$ in the case of horse and beef sausages; however, it decreased for turkey sausage, along with notorious increases of histamine, tyramine and putrescine levels. In particular, histamine in turkey sausage attained a level that is twice the maximum recommended (and enforced) by EC regulations; hence, special care should be exercised regarding consumption of this type of sausage, especially by health compromised or otherwise susceptible individuals.

\section{Acknowledgements}

Author M. A. Rabie received a postdoctoral fellowship (ref. SFRH/BPD/ 67089/2009) from Fundação para a Ciência e a Tecnologia (Portugal) and Fundo Social Europeu (III Quadro Comunitário de Apoio), supervised by author F. X. Malcata.

\section{References}

Alfaia, C. M., Castro, M. F., Reis, V. A., Prates, J. M., de Almeida, I. T., \& Correia, A. D. (2004). Changes in the profile of free amino acids and biogenic amines during the extended short ripening of Portuguese dry cured ham. Food Science and Tech-nology International, 10, 297-304.

Ansorena, D. M., Montel, C., Rokka, M., Talon, R., Eerola, S., \& Rizzo, A. (2002). Analysis of biogenic amines in northern and southern European sausages and role of flora in amine production. Meat Science, 61, 141-147.

Ayhan, K., Kolsarici, N., \& Özkan, G. A. (1999). The effects of a starter culture on the formation of biogenic amines in Turkish soudjoucks. International Journal of Food Microbiology, 53, 183-188. 
Beriain, M. J., Lizaso, G., \& Chasco, J. (2000a). Free amino acids and proteolysis involved in "salchichón" processing. Food Control, 11, 41-47.

Beriain, M. J., Lizaso, G., \& Chasco, J. (2000b). Relationship between biochemical and sensory quality characteristics of different commercial brands of salchichón. Food Control, 11, 231-237.

Bodmer, S., Irmak, C., \& Kneubühl, M. (1999). Biogenic amines in foods: histamine and food processing. Inflammation Research, 48, 296-300.

Bolumar, T., Nieto, P., \& Flores, J. (2001). Acidity, proteolysis and lipolysis changes in rapid cured fermented sausage dried at different temperatures. Food Science and Technology International, 7, 269-276.

Bover-Cid, S., \& Holzapfel, W. H. (1999). Improved screening procedure for biogenic amine production by lactic acid bacteria. International Journal of Food Microbiology, 53, 33-41. Bover-Cid, S., Izquierdo-Pulido, M., \& Vidal-Carou, M. C. (2000). Influence of hygienic quality of raw materials on biogenic amine production during ripening and storage of dry fermented sausages. Journal of Food Protection, 63, 1544-1550.

Bover-Cid, S., Miguélez-Arrizado, M. J., \& Vidal-Carou, M. C. (2001). Biogenic amine ac- cumulation in ripened sausages affected by the addition of sodium sulphite. Meat Science, 59, 391-396.

Bozkurt, H., \& Erkmen, O. (2002). Effect of starter cultures and additives on the quality of Turkish style sausage (sucuk). Meat Science, 61, 149-156.

Bruna, J. M., Fernández, M., Hierro, E. M., Ordóñez, J. A., \& Hoz, L. (2000a). Combined use of a protease (Pronase E) and a fungal extract (Penicillium aurantiogriseum) to improve the sensory characteristics of dry fermented sausages. Meat Science, 54, 135-145.

Bruna, J. M., Fernández, M., Hierro, E. M., Ordóñez, J. A., \& Hoz, L. (2000b). Improvement of the sensory properties of dry fermented sausages by the superficial inoculation and/or the addition of intracellular extracts of Mucor racemosus. Journal of Food Sci-ence, 65, 731-738.

Buscailhon, S., Monin, G., Cornet, M., \& Bousset, J. (1994). Time related changes in ni- trogen fractions and free amino acids of lean tissue of French dry cured ham. Meat Science, 37, 449-456.

Csomos, E., \& Simon-Sarkadi, L. (2002). Characterisation of tokaj wines based on free amino acid and biogenic amine using ion-exchange chromatography. Chromatographia, 56, 185-188.

Dainty, R., \& Blom, H. (1995). Flavour chemistry of fermented sausages. In G. Campbell- Platt, \& P. E. Cook (Eds.), Fermented Meats (pp. 176-193).

Edwards, S. T., Sandine, S., \& Public, L. (1981). Health significance of amine in cheese.Journal of Dairy Science, 64, 2431-2438.

Eerola, S., Roig-Sagués, A. X., \& Hirvi, T. K. (1998). Biogenic amines in Finnish 
dry sau- sages. Journal of Food Safety, 18, 127-138.

Eerola, S., Xavier, A., Lilleberg, L., \& Aalto, H. (1997). Biogenic amines in dry sausages during shelf-life storage. Zeitschrift für Lebensmittel Untersuchung und Forschung A, 205, 351-355.

EFSA - European Food Safety Authority, \& Panel on Biological Hazards (BIOHAZ) (2011). Scientific opinion on risk base control of biogenic amine formation in fermented foods. EFSA Journal, 9, 2393-2486.

Eitenmiller, R. R., \& de Souza, S. C. (1984). Enzymic mechanisms for amine formation in fish. In P. Ragelis (Ed.), Seafood Toxins (pp. 431-442). Washington DC: American Chemical Society.

Erginkaya, Z., \& Varlik, C. (1989). Et ve et ürünlerinde biyojenik aminler. G1da, 14, 171-174.

Ferreira, I. M. P. L. V. O., \& Pinho, O. (2006). Biogenic amines in Portuguese traditional foods and wines. Journal of Food Protection, 69, 2293-2303.

Food and Drug Administration (1990). Decomposition of histamines; raw, frozen tuna and malu malu, canned tuna, and related species. Revised compliance policy guide. Federal Register, 60, 39574-39756.

Halász, A., Baráth, A., Simon-Sarkadi, L., \& Holzapfel, W. (1994). Biogenic amines and their production by microorganisms in food. Trends in Food Science and Technology, $5,42-48$.

Hernandez-Jover, T., Izquierdo-Pulido, M., Veciana-Nogués, M. T., \& Vidal-Carou, M. C. (1996). Biogenic amine sources in cooked cured shoulder pork. Journal of Agricul-tural and Food Chemistry, 44, 3097-3101.

Hernandez-Jover, T., Izquierdo-Pulido, M., Veciana-Nogués, M. T., \& VidalCarou, M. C. (1997). Biogenic amines and polyamine contents in meat and meat products. Jour-nal of Agricultural and Food Chemistry, 45, 2098-2102.

Hierro, E., Hoz, L., \& Ordoñez, J. A. (1999). Contribution of the microbial and meat en-dogenous enzymes to the free amino acid and amine contents of dry fermented sausages. Journal of Agricultural and Food Chemistry, 47, 1156-1161.

Hughes, M. C., Kerry, J. P., Arendt, E. K., Kenneally, P. M., McSweeney, P. L. H., \& O'Neill, E. E. (2002). Characterization of proteolysis during the ripening of semidry fermented sausages. Meat Science, 62, 205-216.

Joosten, H. M. L. J. (1988). The biogenic amine contents of Dutch cheese and their tox- icological significance. Netherlands Milk and Dairy Journal, 42, 25-42.

Jung, H. P. K., \& Bjeldanes, L. F. (1979). Effects of cadaverine on histamine transport and metabolism in isolated gut sections of the guinea pig. Food and Cosmetics Toxicolo- gy, 17, 629.

Komprda, T., Neznalovà, J., Standara, S., \& Bover-Cid, S. (2001). Effect of starter culture and storage temperature on the content of biogenic amines in dry fermented sau- sages polièan. Meat Science, 59, 267-276. 
Konings, W. N., Lolkema, J. S., Bolhuis, H., van Veen, H. W., Poolman, B., \& Driessen, A. J.M. (1997). The role of transport processes in survival of lactic acid bacteria. Antonie Van Leeuwenhoek, 71, 117-128.

Lorenzo, J., Michinel, M., López, M., \& Carballo, J. (2000). Biochemical characteristics of two Spanish traditional dry-cured sausage varieties: Androlla and Botillo. Journal of Food Composition and Analysis, 13, 809-817.

Luthy, J., \& Schlatter, C. (1983). Biogene amine in Lebensmitteht zur wirkung von his- tamine, tyramin und B-phenylethylamin auf den menschen. Zeitschrift für Lebensmittel Untersuchung und- Forschung A, 177, 439-443.

Maijala, R., Eerola, S., Aho, M., \& Hirn, J. (1993). The effect of GDL-induced pH decrease on the formation of biogenic amines in meat. Journal of Food Protection, 56, 125-129.

Martin, L., Antequera, T., Ruiz, J., Cava, R., Tejeda, J. F., \& Cordoba, J. J. (1998). Influence of the processing conditions of Iberian ham on proteolysis during ripening. Food Science and Technology International, 4, 17-22.

Martin, L., Antequera, T., Ventanas, J., Menitez-Donoso, R., \& Cordoba, J. J. (2001). Free amino acids and other non-volatile compounds formed during processing of Iberi- an ham. Meat Science, 59, 363-368.

Montel, M. C., Masson, F., \& Talon, R. (1998). Bacterial role in flavour development. Meat Science, 49, 111-123.

Ordóñez, J. A., Hierro, E. M., Bruna, J. M., \& Hoz, L. (1999). Changes in the components of dry fermented sausages during ripening. Critical Reviews in Food Science and Nutrition, 39, 329-367.

Parente, E., Martuscelli, M., Gardini, F., Grieco, S., Crudele, M. A., \& Suzzi, G. (2001). Evo- lution of microbial populations and biogenic amine production in dry sausages produced in southern Italy. Journal of Applied Microbiology, 90, 882891.

Patterson, R. L., \& Mottram, D. S. (1974). The occurrence of volatile amines in uncured and cured pork meat and their possible role in nitrosamine formation in bacon. Journal of the Science of Food and Agriculture, 25, 1419-1425.

Pechanek, U., Woidich, H., \& Pfannhauser, W. (1983). Untersuchung über den Gehalt biogener Amine in vier Gruppen von Lebensmitteln des österreichischen Marktes. Zeitschrift für Lebensmittel-Untersuchung und -Forschung, 176, 335-340.

Rabie, A. M., Siliha, H., el-Saidy, S., el-Badawy, A. A., \& Malcata, F. X. (2010). Effects of $\gamma^{-}$irradiation upon biogenic amine formation in Egyptian ripened sausages during storage. Innovative Food Science and Emerging Technologies, 11, 661-665.

Roig-Sagués, A. X., Hernández-Herrero, M., López-Sabater, E. I., Rodriguez-Jerez, J. J., \& Mora-Ventura, M. T. (1999). Microbiological events during the elaboration of "fuet", a Spanish ripened sausage. Relationships between the development of his- 
tidine and tyrosine decarboxylase containing bacteria and $\mathrm{pH}$ and water activity. European Food Research and Technology, 209, 108-112.

Ruiz, J., Garcia, C., Diaz, M. C., Cava, R., Tejeda, F. J., \& Ventanas, J. (1999). Dry cured Ibe- rian ham non-volatile components as affected by the length of the curing process. Food Research International, 32, 643-651.

Ruiz-Capillas, C., \& Jiménez-Colmenero, F. (2004). Biogenic amines in meat and meat products. Critical Reviews in Food Science, 44, 489-499.

Santos, C., Jalon, M., \& Marine, A. (1985). Contenido de tiramina en alimentos de origen animal. I. Carne, derivados cárnicos y productos relacionados. Revista de Agroquímica y Tecnología de Alimentos, 25, 362-368.

Şenöz, B., Işıklı, N., \& Çoksöyler, N. (2000). Biogenic amines in Turkish sausages (sucuks). Journal of Food Science, 65, 764-767.

Shalaby, A. R. (1996). Significance of biogenic amines to food safety and human health.

Food Research International, 29, 675-690.

Silla-Santos, M. H. (1996). Biogenic amines: their importance in foods. International Journal of Food Microbiology, 29, 213-231.

Simon-Sarkadi, L., \& Holzapfel, W. (1994). Determination of biogenic amines in leafy vegetables by amino acid analyser. Zeitschrift für Lebensmittel Untersuchung und-Forschung A, 198, 220-233.

Stratton, J. E., Hutkins, R. W., \& Taylor, S. L. (1991). Biogenic amines in cheese and other fermented foods: a review. Journal of Food Protection, 54, 460-470.

Taylor, S. L. (1985). Histamine Poisoning Associated with Fish, Cheese and Other Foods.

World Health, Organization - VPH/FOS/85.1.

Taylor, E., Lieber, R., \& Leatherwood, M. (1978). A simplified method for histamine analysis of food. Journal of Food Science, 43, 247-250.

ten Brink, B., Damink, C., Joosten, H. M. L. J., \& Huis in't Veld, J. H. J. (1990). Occurrence and formation of biological amines in food. International Journal of Food Microbiology, 11, 73-84.

Ventanas, J., Cordoba, J. J., Antequera, T., Garcìa, C., López-Bote, C., \& Asensio, M. A. (1992). Hydrolysis and Maillard reactions during ripening of Iberian ham. Journal of Food Science, 57, 813-815.

Virgili, R., Saccani, G., Gabba, L., Tanzi, E., \& Bordini, C. S. (2007). Changes of free amino acids and biogenic amines during extended ageing of Italian dry cured ham. Zeitschrift für Lebensmittel-Untersuchung und -Forschung, 40, 871-878. 

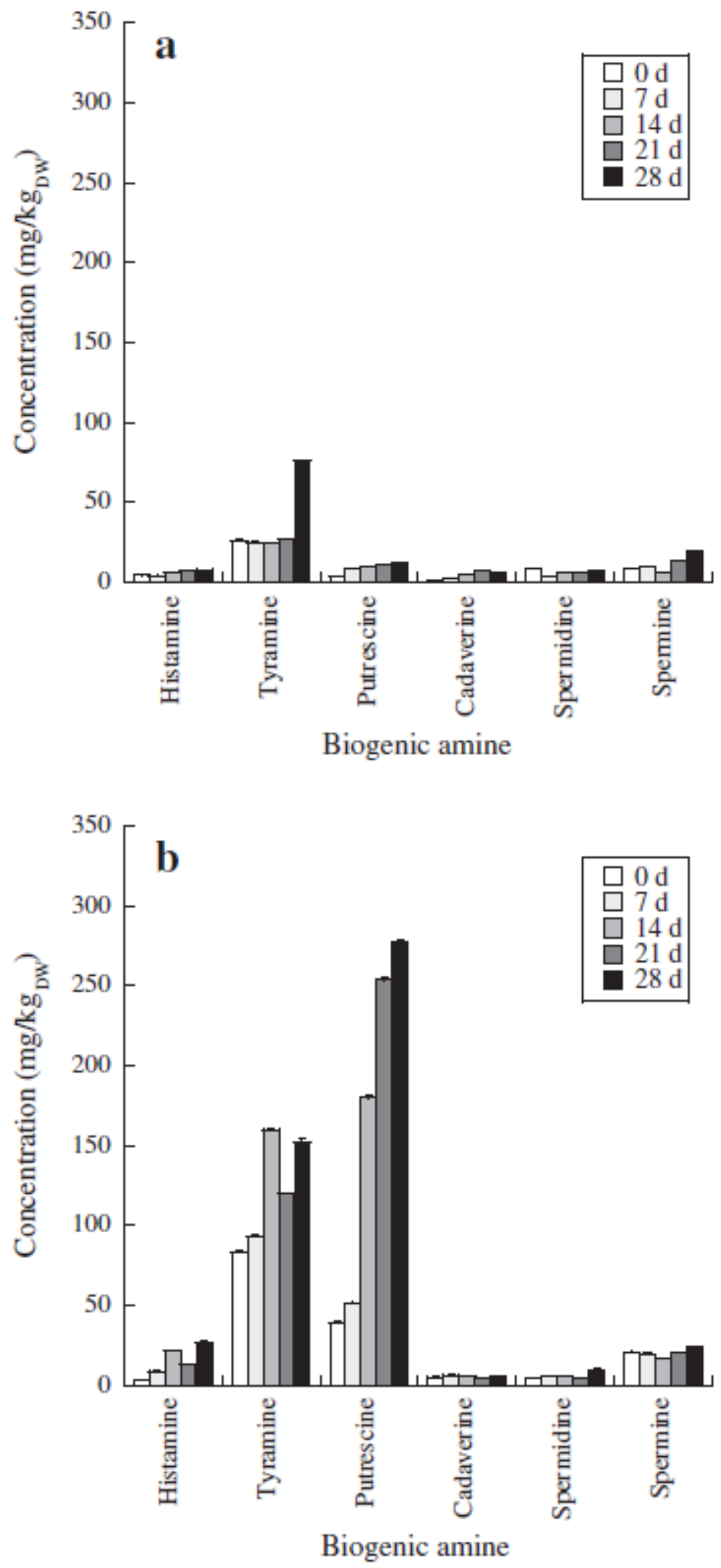


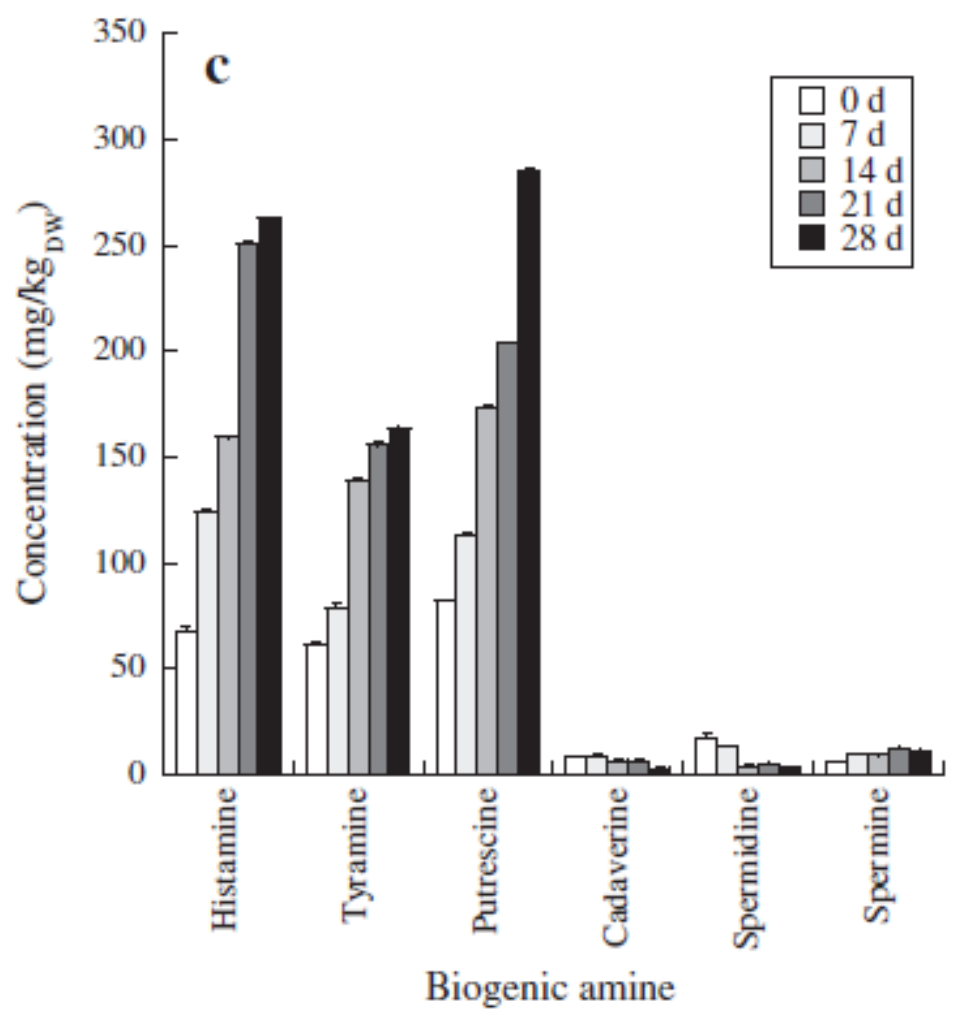

Fig. 1. Evolution, with storage time, of the concentration of selected biogenic amines in (a) horse, (b) beef and (c) turkey sausages (average \pm standard deviation, $n=3$ ) 
Table 1

Evolution, with storage time, of the concentration $(\mathrm{mg} / \mathrm{kgDW})$ of each and the total amino acids, and the total biogenic amines in horse sausages (average \pm standard deviation,

$n=3$; figures within the same line followed by different letters are significantly different at $P$ b 0.05 ).

\begin{tabular}{|c|c|c|c|c|c|}
\hline \multirow[t]{2}{*}{ Amino acid } & \multicolumn{5}{|c|}{ Storage time (d) } \\
\hline & 0 & 7 & 14 & 21 & 28 \\
\hline Aspartic acid & $0.20 \pm 0.01 a$ & $0.47 \pm 0.01 a$ & $1.14 \pm 0.15 a$ & $0.30 \pm 0.02 \mathrm{a}$ & $3.91 \pm 0.19 b$ \\
\hline Threonine & $0.43 \pm 0.02 \mathrm{a}$ & $0.78 \pm 0.03 a$ & $1.30 \pm 0.13 a$ & $0.54 \pm 0.01 a$ & $6.26 \pm 0.01 b$ \\
\hline Serine & $0.65 \pm 0.01 a$ & $1.34 \pm 0.04 a$ & $1.91 \pm 0.06 a$ & $0.89 \pm 0.01 a$ & $5.52 \pm 0.63 b$ \\
\hline Asparagine & $0.00 \pm 0.00 \mathrm{a}$ & $0.02 \pm 0.01 \mathrm{a}$ & $1.62 \pm 0.04 b$ & $0.06 \pm 0.00 \mathrm{a}$ & $3.00 \pm 0.05 c$ \\
\hline Glutamic acid & $0.47 \pm 0.01 a$ & $0.91 \pm 0.01 \mathrm{a}$ & $1.71 \pm 0.04 \mathrm{a}$ & $0.70 \pm 0.04 a$ & $8.18 \pm 0.60 b$ \\
\hline Glutamine & $0.31 \pm 0.06 a$ & $1.36 \pm 0.01 \mathrm{a}$ & $0.09 \pm 0.03 a$ & $1.16 \pm 0.04 a$ & $4.07 \pm 0.35 b$ \\
\hline$\beta$-Alanine & $0.00 \pm 0.00 \mathrm{a}$ & $0.04 \pm 0.00 \mathrm{a}$ & $2.33 \pm 0.07 b$ & $0.04 \pm 0.01 a$ & $2.81 \pm 0.14 b$ \\
\hline Proline & $0.70 \pm 0.07 a$ & $1.55 \pm 0.05 b$ & $3.75 \pm 0.03 c$ & $1.19 \pm 0.02 b$ & $10.15 \pm 0.08 d$ \\
\hline Glycine & $1.54 \pm 0.04 a$ & $3.07 \pm 0.04 b$ & $11.86 \pm 0.67 \mathrm{c}$ & $17.36 \pm 0.04 d$ & $20.96 \pm 0.69 d$ \\
\hline Alanine & $3.79 \pm 0.02 \mathrm{a}$ & $7.56 \pm 0.03 b$ & $2.20 \pm 0.05 a$ & $5.56 \pm 0.31 b$ & $6.19 \pm 0.03 b$ \\
\hline Valine & $0.58 \pm 0.01 a$ & $1.11 \pm 0.03 a$ & $0.02 \pm 0.01 a$ & $0.79 \pm 0.02 \mathrm{a}$ & $3.04 \pm 0.62 b$ \\
\hline Cysteine & $0.00 \pm 0.00 \mathrm{a}$ & $0.02 \pm 0.00 \mathrm{a}$ & $0.49 \pm 0.01 a$ & $0.00 \pm 0.00 \mathrm{a}$ & $2.08 \pm 0.20 \mathrm{~b}$ \\
\hline Methionine & $0.15 \pm 0.02 \mathrm{a}$ & $0.35 \pm 0.03 a$ & $0.06 \pm 0.01 a$ & $0.18 \pm 0.03 a$ & $23.20 \pm 0.46 b$ \\
\hline Cysteine & $0.00 \pm 0.00 \mathrm{a}$ & $0.02 \pm 0.01 \mathrm{a}$ & $1.32 \pm 0.02 \mathrm{a}$ & $0.06 \pm 0.00 \mathrm{a}$ & $1.58 \pm 0.06 \mathrm{~b}$ \\
\hline Isoleucine & $0.29 \pm 0.02 \mathrm{a}$ & $0.59 \pm 0.02 \mathrm{a}$ & $1.60 \pm 0.03 \mathrm{~b}$ & $0.43 \pm 0.02 \mathrm{a}$ & $5.54 \pm 0.62 c$ \\
\hline Leucine & $0.33 \pm 0.03 a$ & $0.82 \pm 0.03 a$ & $0.25 \pm 0.01 a$ & $0.51 \pm 0.01 \mathrm{a}$ & $6.84 \pm 0.67 b$ \\
\hline Tyrosine & $0.14 \pm 0.02 \mathrm{a}$ & $0.20 \pm 0.01 \mathrm{a}$ & $0.35 \pm 0.02 \mathrm{a}$ & $0.16 \pm 0.01 a$ & $7.09 \pm 0.67 b$ \\
\hline Phenylalanine & $0.09 \pm 0.01 a$ & $0.20 \pm 0.02 a$ & $0.49 \pm 0.01 a$ & $0.13 \pm 0.00 \mathrm{a}$ & $5.42 \pm 0.55 b$ \\
\hline Lysine & $1.15 \pm 0.01 a$ & $2.02 \pm 0.08 a$ & $2.94 \pm 0.03 a$ & $1.52 \pm 0.03 a$ & $7.24 \pm 0.72 b$ \\
\hline Histidine & $0.42 \pm 0.02 \mathrm{a}$ & $0.78 \pm 0.02 a$ & $0.88 \pm 0.04 a$ & $0.68 \pm 0.12 a$ & $6.39 \pm 0.60 \mathrm{~b}$ \\
\hline 1- Methyl- histidine & $0.35 \pm 0.01 a$ & $0.90 \pm 0.02 a$ & $1.33 \pm 0.04 a$ & $9.31 \pm 0.03 \mathrm{~b}$ & $7.39 \pm 0.08 b$ \\
\hline Arginine & $0.58 \pm 0.01 a$ & $1.13 \pm 0.07 a$ & $1.66 \pm 0.03 a$ & $0.91 \pm 0.01 a$ & $9.07 \pm 0.38 b$ \\
\hline Total amino acids & 12.15 & 25.21 & 39.31 & 42.49 & 155.95 \\
\hline Total biogenic amines & 52.26 & 53.51 & 55.59 & 71.06 & 126.87 \\
\hline
\end{tabular}


Table 2

Evolution, with storage time, of the concentration $(\mathrm{mg} / \mathrm{kgDW})$ of each and the total amino acids, and the total biogenic amines in beef sausages (average \pm standard deviation, $n=3$; figures within the same line followed by different letters are significantly different at $P$ b 0.05).

\begin{tabular}{|c|c|c|c|c|c|}
\hline \multirow[t]{2}{*}{ Amino acid } & \multicolumn{5}{|c|}{ Storage time (d) } \\
\hline & 0 & 7 & 14 & 21 & 28 \\
\hline Aspartic acid & $0.61 \pm 0.20 \mathrm{a}$ & $0.46 \pm 0.01 a$ & $0.51 \pm 0.03 \mathrm{a}$ & $0.72 \pm 0.05 a$ & $44.39 \pm 0.18 b$ \\
\hline Threonine & $1.95 \pm 0.42 \mathrm{a}$ & $1.79 \pm 0.08 a$ & $2.00 \pm 0.01 a$ & $2.60 \pm 0.10 a$ & $1.35 \pm 0.05 a$ \\
\hline Serine & $1.76 \pm 0.13 a$ & $2.01 \pm 0.04 a$ & $2.27 \pm 0.03 a$ & $3.28 \pm 0.13 b$ & $1.59 \pm 0.12 \mathrm{a}$ \\
\hline Asparagine & $0.08 \pm 0.02 \mathrm{a}$ & $0.59 \pm 0.45 a$ & $0.09 \pm 0.00 a$ & $0.00 \pm 0.00 a$ & $7.67 \pm 0.02 b$ \\
\hline Glutamic acid & $1.10 \pm 0.05 a$ & $1.25 \pm 0.03 \mathrm{a}$ & $1.36 \pm 0.04 a$ & $1.77 \pm 0.02 b$ & $0.57 \pm 0.41 \mathrm{a}$ \\
\hline Glutamine & $3.76 \pm 0.30 \mathrm{a}$ & $3.83 \pm 0.09 a$ & $4.87 \pm 0.08 a$ & $1.63 \pm 0.09 b$ & $4.11 \pm 0.04 a$ \\
\hline$\beta$-Alanine & $0.12 \pm 0.02 \mathrm{a}$ & $0.11 \pm 0.02 \mathrm{a}$ & $0.14 \pm 0.01 a$ & $0.07 \pm 0.02 \mathrm{a}$ & $0.10 \pm 0.01 a$ \\
\hline Proline & $0.97 \pm 0.09 \mathrm{a}$ & $0.82 \pm 0.05 a$ & $0.91 \pm 0.10 \mathrm{a}$ & $1.63 \pm 0.07 a$ & $0.56 \pm 0.05 a$ \\
\hline Glycine & $2.98 \pm 0.10 a$ & $3.20 \pm 0.04 a$ & $3.65 \pm 0.05 a$ & $4.10 \pm 0.13 a$ & $20.16 \pm 0.20 b$ \\
\hline Alanine & $7.63 \pm 0.12 \mathrm{a}$ & $7.49 \pm 1.18 \mathrm{a}$ & $10.62 \pm 0.12 \mathrm{a}$ & $12.97 \pm 0.31 a$ & $63.41 \pm 1.02 b$ \\
\hline Valine & $1.94 \pm 0.10 \mathrm{a}$ & $2.57 \pm 0.45 a$ & $2.44 \pm 0.12 \mathrm{a}$ & $3.78 \pm 0.15 b$ & $1.64 \pm 0.04 a$ \\
\hline Cysteine & $0.06 \pm 0.01 a$ & $0.07 \pm 0.01 a$ & $0.07 \pm 0.01 a$ & $0.09 \pm 0.02 \mathrm{a}$ & $0.05 \pm 0.01 \mathrm{a}$ \\
\hline Methionine & $1.09 \pm 0.12 \mathrm{a}$ & $1.66 \pm 0.22 \mathrm{a}$ & $1.86 \pm 0.16 a$ & $1.70 \pm 0.02 \mathrm{a}$ & $1.12 \pm 0.10 \mathrm{a}$ \\
\hline Cysteine & $0.00 \pm 0.00 \mathrm{a}$ & $0.00 \pm 0.00 \mathrm{a}$ & $0.00 \pm 0.00 \mathrm{a}$ & $0.04 \pm 0.02 \mathrm{a}$ & $0.00 \pm 0.00 \mathrm{a}$ \\
\hline Isoleucine & $1.26 \pm 0.07 \mathrm{a}$ & $1.25 \pm 0.10 \mathrm{a}$ & $1.67 \pm 0.05 a$ & $1.85 \pm 0.03 a$ & $0.94 \pm 0.06 a$ \\
\hline Leucine & $3.75 \pm 0.14 a$ & $5.11 \pm 0.07 a$ & $5.91 \pm 0.12 b$ & $5.96 \pm 0.17 b$ & $7.19 \pm 0.16 b$ \\
\hline Tyrosine & $0.25 \pm 0.03 a$ & $0.34 \pm 0.03 a$ & $0.33 \pm 0.02 \mathrm{a}$ & $0.55 \pm 0.14 \mathrm{a}$ & $0.11 \pm 0.08 \mathrm{a}$ \\
\hline Phenylalanine & $1.30 \pm 0.08 a$ & $1.52 \pm 0.06 a$ & $1.82 \pm 0.06 a$ & $1.91 \pm 0.17 \mathrm{a}$ & $0.99 \pm 0.06 a$ \\
\hline Lysine & $2.70 \pm 0.22 \mathrm{a}$ & $3.60 \pm 0.32 \mathrm{a}$ & $3.90 \pm 0.05 a$ & $2.71 \pm 0.05 a$ & $4.22 \pm 0.16 b$ \\
\hline Histidine & $0.87 \pm 0.10 \mathrm{a}$ & $1.06 \pm 0.16 a$ & $1.03 \pm 0.10 \mathrm{a}$ & $0.93 \pm 0.11 \mathrm{a}$ & $0.41 \pm 0.29 \mathrm{a}$ \\
\hline 1- Methyl- histidine & $1.34 \pm 0.08 \mathrm{a}$ & $1.77 \pm 0.21 \mathrm{a}$ & $2.15 \pm 0.19 b$ & $1.74 \pm 0.17 a$ & $0.98 \pm 0.02 a$ \\
\hline Arginine & $0.10 \pm 0.02 \mathrm{a}$ & $0.11 \pm 0.02 \mathrm{a}$ & $0.17 \pm 0.01 a$ & $0.09 \pm 0.01 \mathrm{a}$ & $0.09 \pm 0.01 a$ \\
\hline Total amino acids & 35.63 & 40.60 & 47.77 & 50.14 & 161.67 \\
\hline Total biogenic amines & 154.95 & 183.87 & 389.93 & 415.31 & 495.99 \\
\hline
\end{tabular}


Table 3

Evolution, with storage time, of the concentration ( $\mathrm{mg} / \mathrm{kgDW}$ ) of each and the total amino acids, and the total biogenic amines in turkey sausages (average \pm standard deviation,

$n=3$; figures within the same line followed by different letters are significantly different at $P$ b 0.05).

\begin{tabular}{|c|c|c|c|c|c|}
\hline \multirow[t]{2}{*}{ Amino acid } & \multicolumn{5}{|l|}{ Storage time (d) } \\
\hline & 0 & 7 & 14 & 21 & 28 \\
\hline Aspartic acid & $0.53 \pm 0.08 \mathrm{a}$ & $0.99 \pm 0.07 a$ & $0.38 \pm 0.03 a$ & $0.62 \pm 0.08 \mathrm{a}$ & $0.56 \pm 0.04 a$ \\
\hline Threonine & $0.75 \pm 0.05 a$ & $1.43 \pm 0.09 a$ & $0.64 \pm 0.00 \mathrm{a}$ & $0.81 \pm 0.02 \mathrm{a}$ & $0.85 \pm 0.04 a$ \\
\hline Serine & $1.22 \pm 0.06 a$ & $2.35 \pm 0.03 a$ & $10.97 \pm 0.40 \mathrm{~b}$ & $1.56 \pm 0.04 a$ & $1.55 \pm 0.22 \mathrm{a}$ \\
\hline Asparagine & $0.29 \pm 0.00 \mathrm{a}$ & $0.00 \pm 0.00 \mathrm{a}$ & $0.27 \pm 0.02 a$ & $0.00 \pm 0.00 \mathrm{a}$ & $0.00 \pm 0.00 \mathrm{a}$ \\
\hline Glutamic acid & $0.16 \pm 0.01 a$ & $0.75 \pm 0.05 a$ & $0.15 \pm 0.03 a$ & $0.32 \pm 0.04 a$ & $0.42 \pm 0.02 \mathrm{a}$ \\
\hline Glutamine & $0.28 \pm 0.02 \mathrm{a}$ & $0.65 \pm 0.08 a$ & $0.08 \pm 0.02 \mathrm{a}$ & $0.16 \pm 0.07 a$ & $0.30 \pm 0.02 a$ \\
\hline$\beta$-Alanine & $0.00 \pm 0.00 \mathrm{a}$ & $0.03 \pm 0.01 a$ & $0.02 \pm 0.01 a$ & $0.25 \pm 0.28 a$ & $0.02 \pm 0.00 \mathrm{a}$ \\
\hline Proline & $1.20 \pm 0.04 a$ & $2.03 \pm 0.10 \mathrm{a}$ & $0.95 \pm 0.05 a$ & $1.47 \pm 0.09 \mathrm{a}$ & $1.31 \pm 0.09 \mathrm{a}$ \\
\hline Glycine & $2.23 \pm 0.08 \mathrm{a}$ & $3.91 \pm 0.13 \mathrm{~b}$ & $1.80 \pm 0.04 a$ & $3.18 \pm 0.05 b$ & $2.33 \pm 0.02 a$ \\
\hline Alanine & $35.60 \pm 0.75 a$ & $6.95 \pm 0.04 b$ & $3.29 \pm 0.06 \mathrm{~b}$ & $6.46 \pm 0.15 b$ & $4.35 \pm 0.13 \mathrm{~b}$ \\
\hline Valine & $0.75 \pm 0.04 a$ & $1.66 \pm 0.13 a$ & $0.63 \pm 0.01 a$ & $1.12 \pm 0.09 \mathrm{a}$ & $0.94 \pm 0.05 a$ \\
\hline Cysteine & $0.00 \pm 0.00 \mathrm{a}$ & $0.02 \pm 0.01 a$ & $0.11 \pm 0.01 a$ & $0.02 \pm 0.01 a$ & $0.00 \pm 0.00 a$ \\
\hline Methionine & $0.29 \pm 0.02 a$ & $0.56 \pm 0.02 a$ & $0.21 \pm 0.02 a$ & $1.77 \pm 0.04 b$ & $0.34 \pm 0.01 a$ \\
\hline Cysteine & $0.00 \pm 0.00 \mathrm{a}$ & $0.00 \pm 0.00 \mathrm{a}$ & $0.00 \pm 0.00 \mathrm{a}$ & $0.00 \pm 0.00 \mathrm{a}$ & $0.00 \pm 0.00 \mathrm{a}$ \\
\hline Isoleucine & $0.53 \pm 0.07 a$ & $0.93 \pm 0.05 a$ & $0.42 \pm 0.07 a$ & $0.51 \pm 0.07 a$ & $0.53 \pm 0.02 a$ \\
\hline Leucine & $1.04 \pm 0.01 \mathrm{a}$ & $1.99 \pm 0.04 b$ & $0.88 \pm 0.07 a$ & $0.99 \pm 0.03 a$ & $1.22 \pm 0.02 \mathrm{a}$ \\
\hline Tyrosine & $0.14 \pm 0.06 a$ & $0.00 \pm 0.00 \mathrm{a}$ & $0.07 \pm 0.00 \mathrm{a}$ & $0.60 \pm 0.62 a$ & $0.10 \pm 0.00 a$ \\
\hline Phenylalanine & $0.29 \pm 0.02 \mathrm{a}$ & $0.54 \pm 0.08 a$ & $0.19 \pm 0.00 \mathrm{a}$ & $0.30 \pm 0.05 a$ & $0.33 \pm 0.01 a$ \\
\hline Lysine & $1.65 \pm 0.15 a$ & $2.89 \pm 0.10 \mathrm{~b}$ & $1.25 \pm 0.02 \mathrm{a}$ & $0.03 \pm 0.02 \mathrm{a}$ & $1.75 \pm 0.06 a$ \\
\hline Histidine & $0.25 \pm 0.02 \mathrm{a}$ & $0.46 \pm 0.02 \mathrm{a}$ & $0.19 \pm 0.02 \mathrm{a}$ & $0.13 \pm 0.02 \mathrm{a}$ & $0.24 \pm 0.03 a$ \\
\hline 1- Methyl- histidine & $0.63 \pm 0.05 a$ & $1.22 \pm 0.03 a$ & $0.47 \pm 0.01 a$ & $0.46 \pm 0.02 \mathrm{a}$ & $0.65 \pm 0.03 a$ \\
\hline Arginine & $0.15 \pm 0.02 \mathrm{a}$ & $0.20 \pm 0.03 a$ & $0.12 \pm 0.03 a$ & $0.11 \pm 0.01 a$ & $0.15 \pm 0.03 a$ \\
\hline Total amino acids & 48.01 & 29.51 & 23.09 & 20.87 & 17.93 \\
\hline Total biogenic amines & 244.55 & 348.75 & 492.59 & 634.72 & 730.30 \\
\hline
\end{tabular}

